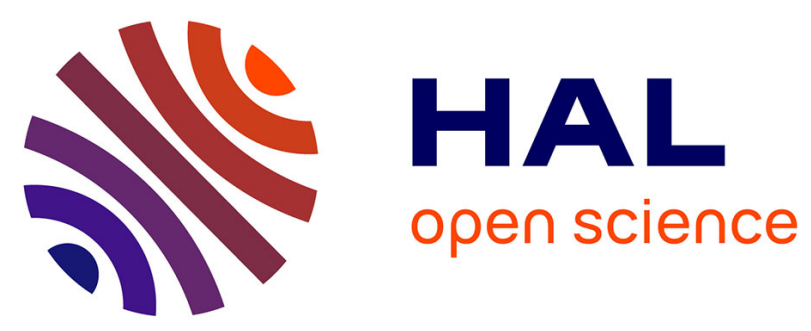

\title{
First data on three bivalve species exposed to an intra-harbour polymetallic contamination (La Rochelle, France)
}

Marine Breitwieser, Amélia Viricel, Carine Churlaud, Benoît Guillot, Elie Martin, Pierre-Louis Stenger, Valérie Huet, Angélique Fontanaud, Hélène Thomas-Guyon

\section{To cite this version:}

Marine Breitwieser, Amélia Viricel, Carine Churlaud, Benoît Guillot, Elie Martin, et al.. First data on three bivalve species exposed to an intra-harbour polymetallic contamination (La Rochelle, France). Comparative Biochemistry and Physiology - Part C: Comparative Pharmacology and Toxicology, 2017, 199, pp.28 - 37. 10.1016/j.cbpc.2017.02.006 . hal-01680279

\section{HAL Id: hal-01680279 \\ https://hal-univ-rochelle.archives-ouvertes.fr/hal-01680279}

Submitted on 3 May 2019

HAL is a multi-disciplinary open access archive for the deposit and dissemination of scientific research documents, whether they are published or not. The documents may come from teaching and research institutions in France or abroad, or from public or private research centers.
L'archive ouverte pluridisciplinaire HAL, est destinée au dépôt et à la diffusion de documents scientifiques de niveau recherche, publiés ou non, émanant des établissements d'enseignement et de recherche français ou étrangers, des laboratoires publics ou privés. 


\title{
Comparative Biochemistry and Physiology, Part C
}

\section{First data on three bivalve species exposed to an intra-harbour polymetallic contamination (La Rochelle, France)}

\author{
Marine Breitwieser ${ }^{\mathrm{a}, \mathrm{b}, *}$, Amélia Viricel ${ }^{\mathrm{a}}$, Carine Churlaud ${ }^{\mathrm{a}}$, Benoit Guillot ${ }^{\mathrm{c}}$, Elie Martin ${ }^{\mathrm{a}}$, Pierre-Louis Stenger ${ }^{\mathrm{a}}$, \\ Valérie Huet $^{\mathrm{a}}$, Angélique Fontanaud ${ }^{\mathrm{b}}$, Hélène Thomas-Guyon ${ }^{\mathrm{a}}$ \\ a Littoral Environnement et Sociétés (LIENSs), UMR 7266, CNRS-Université de La Rochelle, 2 rue Olympe de Gouges, F-17042 La Rochelle Cedex 01, France \\ ${ }^{\mathrm{b}}$ Régie du Port de Plaisance de La Rochelle, Avenue de la Capitainerie, 17000 La Rochelle, France \\ ' UMR CNRS 5805 EPOC - OASU - Université de Bordeaux, Allée Geoffroy Saint-Hilaire, CS 5002333615 Pessac Cedex, France
}

Keywords:

Bivalve

Marina areas

Biomarkers

Heavy metals

Biomonitoring

Diffuse pollution

DNA barcoding

\begin{abstract}
A B S T R A C T
Evaluating diffuse sediment contamination in the environment is a major concern with the aim of reaching a good chemical and ecological state of the littoral zone. In this study the risks of chronic chemical contamination and consequences in the bivalves Crassostrea gigas, Mytilus sp. and Mimachlamys varia were evaluated in coastal environments. The objective here was to understand the anthropological phenomena that affect the functioning of the marina of La Rochelle (semi-closed environment). Harbours seeking ecomanagement accreditations (such as the international reference ISO 14001) constitute zones of interest to implement biomonitoring studies. The biological effects of chemical pollution in the Marina of La Rochelle were studied to develop a multi-biomarker biomonitoring approach on specific marine species of this site. Moreover, a genetic (DNA barcoding) approach was applied to validate the species identity of collected bivalves. Of the three species tested the scallop, $M$. varia, was the most sensitive to metal exposure.
\end{abstract}

\section{Introduction}

Xenobiotics produce alterations in aquatic organisms at different levels and can induce permanent damage. However, these organisms have evolved defences at the biochemical level, which protect them from contamination effects that occur during early exposure. The evaluation of the impact of pollutants in the environment is now a major concern, with the aim of reaching a good chemical and ecological state of the littoral zone. Previous studies (Milinkovitch et al., 2015; Lacroix et al., 2015; Luna-Acosta et al., 2011; Breitwieser et al., 2016) showed the risks of chronic chemical contamination and the consequences in the bivalves Mimachlamys varia, Crassostrea gigas and Mytilus edulis in an open coastal environment. In this context, the objective of this project was to assess the impacts of pollution (heavy metals) on the macrofauna of a semi-closed environment: a marina in La Rochelle (France). We also analyzed samples from two neighbouring zones: the area where muds dredged from the marina are deposited, and a less-

\footnotetext{
* Corresponding author at: Littoral Environnement et Sociétés (LIENSs) UMR 7266 CNRS-Université de La Rochelle, 2 rue Olympe de Gouges, F-17042, La Rochelle Cedex 01, France.

E-mail addresses: marine.breitwieser@univ-lr.fr (M. Breitwieser) carine.churlaud@univ-lr.fr (C. Churlaud), benoit.guillot@u-bordeaux.fr (B. Guillot), valerie.huet@univ-lr.fr (V. Huet), fontanaud@portlarochelle.com (A. Fontanaud), helene.thomas@univ-lr.fr (H. Thomas-Guyon).
}

impacted site on the coast. The department of environment of the La Rochelle Marina has started to implement focused efforts to improve the treatment of careening wastewater (filter with UV, carbon filter and sand filter). Therefore, the present study will constitute a baseline for future biomonitoring studies assessing the benefits of these efforts in terms of environmental quality. Indeed, previous studies in harbour areas from around the world (Egypt, Australia, France, Canada and Cote d'Ivoire) have identified significant enrichment of metal(loid)s in sediments and a crucial need for biomonitoring surveys (Hussein and Khaled, 2014; Walker and MacAskill, 2014; Caro et al., 2015; Bakary et al., 2015; Pippy et al., 2016). In exposed organisms, pollutant-mediated generation of reactive oxygen species (ROS) is likely to induce antioxidant defence mechanisms to prevent oxidative damages to cellular antioxidant enzymes. The measurement of the activity of antioxidant enzymes in mussels, oysters and scallops has been widely used as a biomarker of exposure to environmental pollutants (Lam, 2009; Luna-Acosta et al., 2010; Bustamante and Miramand, 2005). In the present study, we selected exposure biomarkers including glutathione $S$ transferase (GST), laccase immune-marker, malondialdehyde (MDA) and superoxide dismutase (SOD). Malondialdehyde and SOD are effectors of antioxidant defences and have been used to reveal the exposure to metals and a wide range of organic compounds in the environment. Glutathione S-transferases are involved in phase II detoxification of xenobiotics and toxin biotransformation, which also plays a protective 
role against oxidative stress by catalysing a selenium-dependant glutathione peroxidase (Tappel et al., 1982; Prohaska, 1980). Lipid peroxidation indicates the damage to cellular membrane lipids caused by ROS and is useful for assessing exposure to and the effects of pollutants in marine species. Moreover, there is a depletion of key enzymes such as laccase involved in the modulation of immune system in bivalve in presence of contaminants (Luna-Acosta et al., 2010, 2011; Milinkovitch et al., 2015; Breitwieser et al., 2016).

Animals were collected from several intra-harbour stations in order to: (1) quantify the content of inorganic contaminants in sessile marine organisms; and (2) identify an indicator species of intra-harbour pollution. Variations in both trace element levels and biomarker responses among sites were analyzed during winter (low energy metabolism) to assess the potential of $M$. varia as a biomonitoring species in comparison with C. gigas and M. edulis, which are used in watch programs by the $\mathrm{Na}-$ tional Oceanic and Atmospheric Administration (NOAA) for example. We compared these sites, impacted by anthropogenic activities, to a nearby reference site that presents much lower levels of trace metal pollution: Ré Island (Bustamante and Miramand, 2005; Milinkovitch et al., 2015).

Ecotoxicology and biomonitoring studies generally rely on comparisons (e.g. among different conditions) made within a species or subspecies, that is, within a single evolutionary unit. Unknowingly sampling different evolutionary lineages may lead to artefacts or biases when comparing bioaccumulation patterns and stress response across sites or across different years. Indeed, several studies have shown that closely related (sometimes cryptic) species can differ in sensitivity to pollutants (e.g. Sturmbauer et al., 1999; Feckler et al., 2012). Thus, we chose to include a DNA barcoding step in our study, to validate species identification made in the field and to evaluate the presence of cryptic lineages in the study area.

\section{Materials and methods}

\subsection{Field collection and tissue sampling}

The study sites are shown in Fig. 1. Three species (Fig. 2) were collected from four sampling sites in the harbour of La Rochelle (Rainwater, Careening, Fuels (2); $\left.46^{\circ} 14^{\prime} 50.15^{\prime \prime} \mathrm{N},-1^{\circ} 16^{\prime} 67.86^{\prime \prime} \mathrm{W}\right)$, one site right outside the harbour where muds dredged from the marina are deposited (BDM) and one site that was less contaminated (Loix-en-Ré; $46^{\circ} 23^{\prime}$ $\left.09.98^{\prime \prime} \mathrm{N},-1^{\circ} 41^{\prime} 99.63^{\prime \prime} \mathrm{W}\right)$. "Loix-en-Ré" situated in Ré Island was chosen as the reference site. "BDM" is the area of outlet dredging near a touristic beach and close to the harbour, "rainwaters" corresponds to the outlet of rainwaters in the harbour (without a water-filtering system), "careening" is located below the careening area, which has a water-filtering system (carbon, sand, UV and paper to remove organic, inorganic and bacterial contamination). Finally, "fuel (now)" is the recent fueling station for boaters, which has been operating the past 2 years, and "fuel (old)" was the old fueling station, which has not been functional since 2 years ago.

The digestive glands of 60 oysters (C. gigas), 60 mussels (Mytilus sp.) and 60 variegated scallops ( $M$. varia) were collected (adult size, ten individuals of each species per site). A power analysis was conducted to determine the number of replicates that was sufficient to detect significant differences in biomarker activities according to thresholds from previous studies. Our power analysis revealed that eight is the minimum number of individuals per site that should be sampled to reach a power of $80 \%$ (alpha $=0.05$ ).

Sampling and protein assays were carried out in January 2015. For each sampling site, digestive glands of bivalves were removed and stored at $-80{ }^{\circ} \mathrm{C}$ for further analysis. Each digestive gland was cut into two samples and used for trace elements and biochemical assessment of biomarkers (Milinkovitch et al., 2015). Samples for trace element analysis were freeze-dried for $48 \mathrm{~h}$. For each species, muscle tissue from five individuals per site (from the same batch of 60 samples) was collected and stored at $-80^{\circ} \mathrm{C}$ for genetic analysis.

\subsection{Trace element analysis}

Analyses of Ag, As, Cd, Co, Cr, Cu, Fe, Mn, Ni, Pb, Se, Sn, V and Zn were performed with a Varian Vista-Pro ICP-OES and a Thermofisher Scientific XSeries 2 ICP-MS. To this end, aliquots weighing between 60 and $200 \mathrm{mg}$ were digested using a $6: 2(\mathrm{v} / \mathrm{v}) 67-70 \% \mathrm{HNO}_{3} / 34-37 \% \mathrm{HCl}$ mixture (Fisher, trace metal quality). Acidic digestion of the samples was carried out overnight at room temperature and then in a Milestone microwave oven (30 min with constantly increasing temperature up to $120^{\circ} \mathrm{C}$, then $15 \mathrm{~min}$ at this temperature). Each sample was made up to $50 \mathrm{~mL}$ with ultrapure quality water.

For samples with a weight of $<100 \mathrm{mg}$, the mixture used was $3: 1(\mathrm{v} /$ v) $67-70 \% \mathrm{HNO}_{3} / 34-37 \% \mathrm{HCl}$, and the samples were made up to $25 \mathrm{~mL}$ with ultrapure water. Two certified reference materials (CRMs) and one blank, treated and analyzed in the same way as the samples, were included in each analytical batch. CRMs were DOLT-4 (dogfish liver) and TORT-2 (lobster hepatopancreas), which were both from the National Research Council Canada (NRCC). Means recovery rates were (in \%) 104 (As), 103 (Cd), 98 (Co), 98 ( Cr), 91 (Cu), 88 (Fe), 90 (Mn), 97 (Ni), $92(\mathrm{~Pb}), 101(\mathrm{Se}), 95(\mathrm{~V})$ and $104(\mathrm{Zn})$ for TORT2 and $96(\mathrm{Ag}) 92$

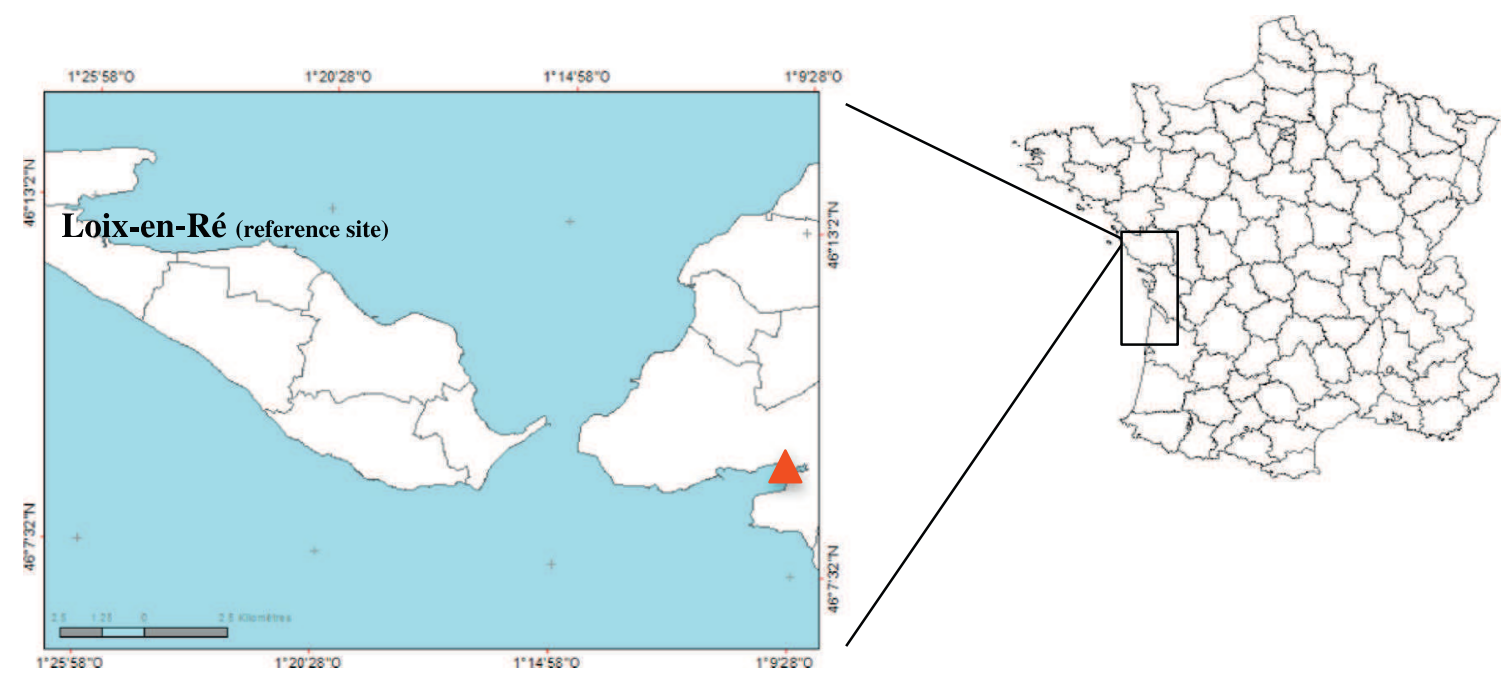

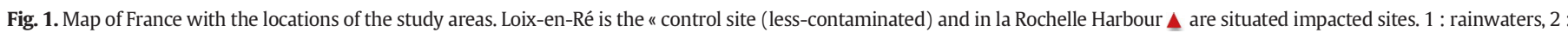
Careening, 3 : Fuel (now), 4 : Fuel (old), 5 : outlet dredging. 
A : Crassostrea gigas
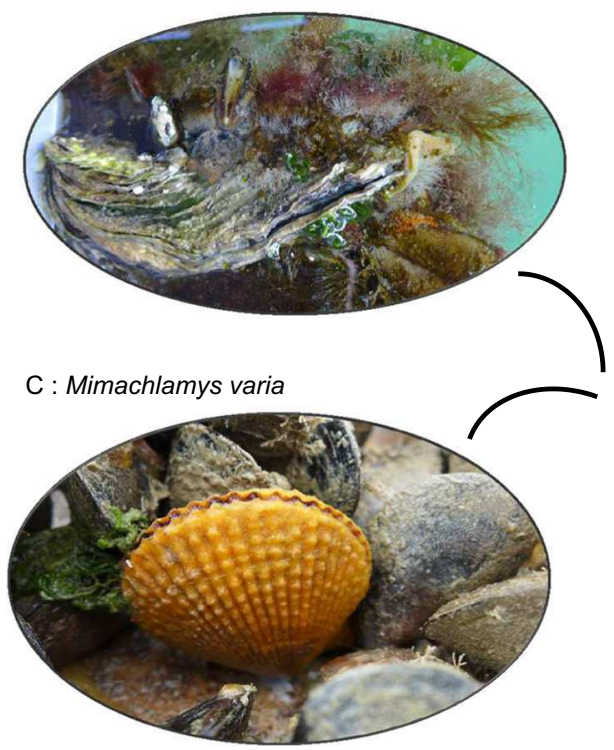

B : Mytilus edulis
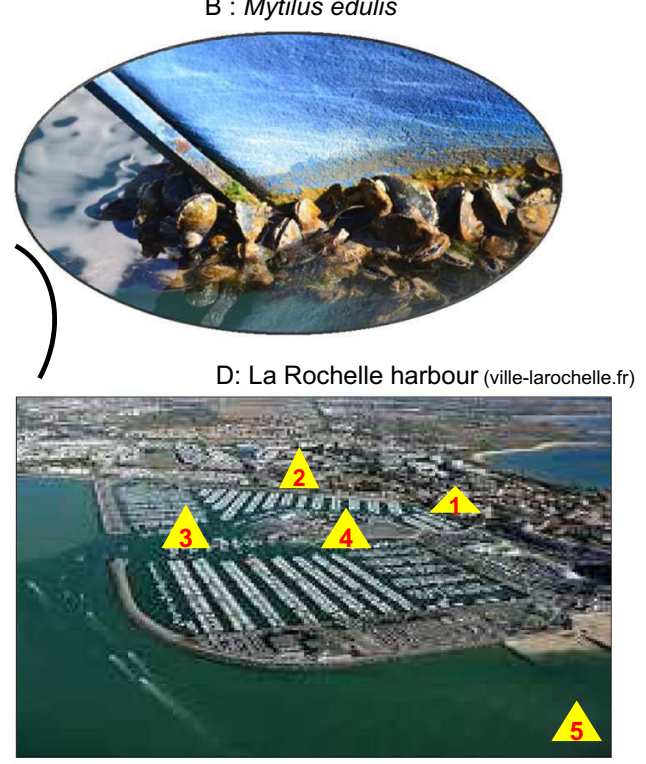

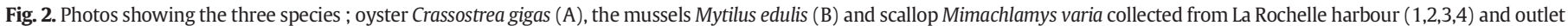
dredging (5) and reference site. Photo credit: Thierry Guyot and ville-larochelle.fr.

(As), 97 (Cd), 99 (Cu), 92 (Fe), 101 (Ni), 95 (Pb), 99 (Se) and 106 (Zn) for DOLT4. Mean element concentrations are expressed in $\mu \mathrm{g} / \mathrm{g}$ of dry weight. Quantification limits were 0.04 (Ag), 0.37 (As), $0.04(\mathrm{Cd}), 0.04$ (Co), 0.04(Cr), $0.18(\mathrm{Cu}), 7.38(\mathrm{Fe}), 0.18(\mathrm{Mn}), 0.07(\mathrm{Ni}), 0.04(\mathrm{~Pb})$, $0.18(\mathrm{Se}), 0.04(\mathrm{Sn}), 0.74(\mathrm{~V})$ and $7.38(\mathrm{Zn}) \mu \mathrm{g} / \mathrm{g}$ of dry weight (Unrine et al., 2007).

\subsection{Biochemical biomarker analysis}

\subsubsection{Sample processing}

For biomarker assessment, samples were homogenised in ice-cold phosphate buffer (100 mM, pH 7.2, 1100 mOsm). The homogenates were centrifuged at $12,500 \mathrm{~g}$ at $4{ }^{\circ} \mathrm{C}$ for $15 \mathrm{~min}$ and the Final Fractions (FF) were used for biochemical assays.

\subsubsection{Total protein concentration}

Total protein concentrations were determined following an adaptation of the BCA Kit methodology (Bicinchononique Acid Kit, Sigma Aldrich). The kit contained bovine serum albumin (BSA) as a standard and involved the reduction of alkaline $\mathrm{Cu}^{2+}$ by proteins (Smith et al., 1985 ) at absorbance $562 \mathrm{~nm}$ using a spectrofluorometer (SAFAS FlxXenius).

\subsubsection{Antioxidant enzyme activities}

SOD activity was assessed in the FF using the method developed by Paoletti et al. (1986). The assay, involving EDTA, $\mathrm{MnCl}_{2}$ and mercaptoethanol, measures the decrease of nicotinamide adenine dinucleotide (NADH) oxidation. This inhibition of oxidation was monitored at $340 \mathrm{~nm}$ (using the SAFAS Flx-Xenius spectrofluorimeter) and is a function of SOD activity. Fifty percent inhibition of oxidation corresponds to one unit of SOD. The results are presented in U of SOD/mg of protein.

GST activity in digestive glands was determined by adapting a Sigma assay kit method. The Glutathione S-Transferase (GST) assay kit utilizes 1-chloro-2,4-dinitrobenzene (CDNB), which is suitable for the broadest range of GST isozymes. Upon conjugation of the thiol group of glutathione to the CDNB substrate, there is an increase in the absorbance at $340 \mathrm{~nm}$ (SAFAS Flx-Xenius). Results are presented in $\mathrm{mU}$ of GST/mg of protein (Mannervik et al., 1988; Habig et al., 1974).

\subsubsection{Laccase assay}

Using a method developed by Luna-Acosta et al. (2010), the activity was measured in the FF. The method is based on the fact that the oxidation of PPD (p-phenylenediamine) is catalysed by laccase. Thus, the activity of laccase-type phenoloxidase (PO) is a function of PPD degradation. The reaction was assessed at $420 \mathrm{~nm}$ using a spectrofluorometer (SAFAS Flx-Xenius). In parallel, the non-enzymatic auto-oxidation (oxidation in the absence of FF) was subtracted. Laccase-type PO activity is expressed as $U$ of laccase/mg of protein (one unit is defined as the amount of enzyme that catalyses the appearance of $1 \mu \mathrm{mol}$ of product per min).

\subsubsection{Lipid peroxidation}

Damage and in particular lipid peroxidation was estimated by assessing the MDA concentration in the FF (Gerard-Monnier et al., 1998). A commercially available MDA assay kit (Oxis International) was used. The method is based on the reaction of MDA with a chromogenic reagent (n-methyl-2-phenylindole). The blue product was quantified by measuring absorbance at $586 \mathrm{~nm}$ (Gerard-Monnier et al., 1998) using the SAFAS Flx-Xenius spectrofluorimeter. The results are presented in $\mu \mathrm{M} . \mathrm{mg}$ prot $^{-1}$.

\subsection{Genetic approach}

DNA was extracted from approximately $15 \mathrm{mg}$ of muscle tissue using the NucleoSpin ${ }^{\circledR}$ Tissue kit (Macherey-Nagel EURL, Hoerdt, France) following the manufacturer's protocol. Species identification of scallops was performed with a portion of the mitochondrial gene coding for cytochrome $c$ oxidase I (cox1) using primers specifically designed for Mimachlamys spp.: forward primer Cox1F3 (5'GGGTTTGGrAACTGGCTTCT-3') and reverse primer Cox1R-long (5'CCAAAAACMCGAATCTTCTT-3') (Breitwieser et al., 2016). The PCR profile was: $94^{\circ} \mathrm{C}$ for $2 \mathrm{~min}$, followed by 30 cycles of $30 \mathrm{~s}$ at $94{ }^{\circ} \mathrm{C}, 30 \mathrm{~s}$ at $54{ }^{\circ} \mathrm{C}$, and $30 \mathrm{~s}$ at $72{ }^{\circ} \mathrm{C}$ and a final extension of $7 \mathrm{~min}$ at $72{ }^{\circ} \mathrm{C}$. The $35 \mu \mathrm{L}$ reactions included $1 \times$ Reaction Buffer (biotechrabbit, Hennigsdorf, Germany), $1.5 \mathrm{mM} \mathrm{MgCl}_{2}, 0.3 \mu \mathrm{M}$ for each primer, 0.15 mM dNTPs, $1.4 \mathrm{U}$ Taq polymerase (biotechrabbit, Hennigsdorf, Germany), and approximately 40 ng DNA. For identification of mussels, the mitochondrial locus 16S rDNA was used, with forward primer 16S RA 
(5'-CGCCTGTTTATCAAAAACAT-3') and reverse primer 16S RB (5'CCGGTCTGAACTCAGATCACGT-3') (Palumbi et al., 1991). The PCR profile was: $95^{\circ} \mathrm{C}$ for $2 \mathrm{~min}$, followed by 35 cycles of $30 \mathrm{~s}$ at $95^{\circ} \mathrm{C}, 30 \mathrm{~s}$ at $48{ }^{\circ} \mathrm{C}$, and $30 \mathrm{~s}$ at $72{ }^{\circ} \mathrm{C}$ and a final extension of $7 \mathrm{~min}$ at $72{ }^{\circ} \mathrm{C}$. For identification of oysters, we used a portion of $\operatorname{cox} 1$, with forward primer LCO 1490 (5'-GGTCAACAAATCATAAAGATATTGG-3') and reverse primer HCO 2198 (5'-TAAACTTCAGGGTGACCAAAAAATCA-3') (Folmer et al., 1994). The PCR profile was: $94^{\circ} \mathrm{C}$ for 2 min, followed by 30 cycles of $30 \mathrm{~s}$ at $94{ }^{\circ} \mathrm{C}, 30 \mathrm{~s}$ at $45^{\circ} \mathrm{C}$, and $30 \mathrm{~s}$ at $72{ }^{\circ} \mathrm{C}$ and a final extension of 7 min at $72^{\circ} \mathrm{C}$. For mussels and oyster, PCR reactions included $1 \times$ Reaction Buffer (biotechrabbit, Hennigsdorf, Germany), $1.5 \mathrm{mM} \mathrm{MgCl}$, $0.3 \mu \mathrm{M}$ for each primer, $0.15 \mathrm{mM}$ dNTPs, $2 \mathrm{U}$ Taq polymerase (biotechrabbit, Hennigsdorf, Germany), and approximately 40 ng DNA in a total reaction volume of $50 \mu \mathrm{L}$. No-template negative controls were included in DNA extractions and PCR reactions. PCR products were sent to Genoscreen (Lille, France) for purification and Sanger sequencing in both directions, except in scallops, for which PCR products were sequenced in one direction using Cox1F3. Sequences were edited manually using Sequencher ${ }^{\circledR}$ v. 4.7 (Gene Codes Corp., Ann Arbor, MI, USA). Species identification was achieved in GenBank using the BLAST function with default parameters (http://blast.ncbi.nlm.nih.gov/Blast. cgi). Additionally, we used Mytilus spp. sequences from Genbank to construct a phylogenetic tree and assess the placement of our mussel sequences within the three clades identified in Gerard et al. (2008) with 16S rDNA data. The 362-bp alignment used to build a tree included 51 Mytilus spp. sequences from the northern hemisphere (Table S2, supplementary data) in addition to our sequences. Using this alignment, we constructed a Neighbor-Joining (NJ) using MEGA v. 5.05 (Tamura et al., 2011). Branch support was assessed using 1000 bootstrap replicates and the Tamura-Nei (Tamura and Nei, 1993) model of substitution was applied as in Gerard et al. (2008). Scallop haplotypes were compared to previously sampled M. varia cox 1 haplotypes (across $477 \mathrm{bp}$ ) obtained for the same geographic area and described in Breitwieser et al. (2016) to evaluate the presence of the same lineages across different years.

\subsection{Data analysis}

Results are expressed as means \pm standard error of the mean. Statistical analyses were carried out using R v. 3.1.2 (R Core Team, 2016). For all variables, normality was first tested on residuals using KolmogorovSmirnov tests and homogeneity of variances was assessed using Bartlett tests. For inorganic contaminant and biomarker values, sites that were presumably more contaminated were compared to values obtained for the reference site (Loix-en-Ré) using One-Sample $t$-tests. These tests were performed for each of the three species separately. For biomarkers, values obtained at the reference site were compared among the three species using a One-way ANOVA. Moreover, a multi-correlation Spearman test was used to highlight correlations between inorganic contaminants concentrations and biomarkers values.

\section{Results}

\subsection{Trace element concentrations}

\subsubsection{Trace element concentrations for $\mathrm{C}$. gigas}

Trace element concentrations are presented in Table 1 . Tissue $\mathrm{Cu}$ concentrations were significantly different between the reference site and all the other sites, with the highest contamination recorded in the careening area of the harbour, and the lowest contamination for those from Ré Island. For $\mathrm{Cu}$ and $\mathrm{Zn}$, significant differences $(p<0.05)$ were found between all harbour areas and Ré Island, whereas for Ag, significant differences were only found between the rainwater area and Ré Island. For Cd, concentrations in the digestive glands of oysters were higher in the Marina of La Rochelle when compared to those from Ré Island. Other trace elements did not show significant variation in concentrations between the reference and impacted sites.

\subsubsection{Trace element concentrations for $\mathrm{M}$. edulis}

Trace element concentrations in mussels are presented in Table 2. Co concentrations were significantly higher in the careening area than in the reference site. Pb concentrations showed significantly higher values in two impacted sites (rainwaters and old fuel area) and a lower value in the recent fuel area (fuel now) compared to Ré island. Cu concentrations were higher inside the Marina (careening, rainwaters and fuels areas) compared to the reference site. Concerning $\mathrm{Ni}$ and $\mathrm{Mn}$, concentrations were significantly lower for rainwaters and fuel (old), respectively. Moreover, Mn and Se concentrations were significantly higher for rainwaters and outlet dredging, respectively. Other trace elements did not show significant variation in concentrations between the control and impacted sites.

\subsubsection{Trace element concentrations for $\mathrm{M}$. varia}

Trace element concentrations are presented in Table 3. $\mathrm{Mn}$ and $\mathrm{Cu}$ concentrations were significantly different between the reference site and all the other sites, with the lowest contamination for those from Ré island. Fe concentrations were significantly higher in scallops from all sites within the Marina compared to the reference site. Significantly lower concentrations of $\mathrm{Zn}$ in scallops from the old fuel area were observed, while concentrations of this element were significantly higher in the rainwaters area, in comparison with the reference site Ré island. Finally, lower concentrations of Cd were recorded at impacted sites compared to the reference site, except for the outlet dredging area.

Table 1

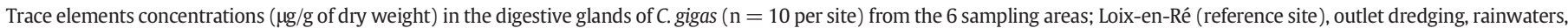
careening and fuels (now and old) areas. Different letters $\left({ }^{\mathbf{a}, \mathbf{b}}\right)$ above values indicate a significant difference where $p<0.05$.

\begin{tabular}{|c|c|c|c|c|c|c|}
\hline Tab. I & $\begin{array}{l}\text { Reference } \\
\text { Loix en Ré }\end{array}$ & $\begin{array}{l}\text { BDM } \\
\text { Outlet dredging }\end{array}$ & Outlet rainwaters & Careening area & Fuel area (now) & Fuel area (old) \\
\hline As & $34.22 \pm 1.5$ & $20.0 \pm 1$ & $28.87 \pm 1.2$ & $26.73 \pm 1.35$ & $24.78 \pm 1.7$ & $28.38 \pm 1.92$ \\
\hline $\mathrm{Cd}$ & $2.18 \pm 0.19$ & $2.49 \pm 0.11$ & $4.71 \pm 0.52$ & $4.28 \pm 0.39$ & $3.79 \pm 0.39$ & $4.59 \pm 0.50$ \\
\hline Co & $0.47 \pm 0.04$ & $0.31 \pm 0.04$ & $0.52 \pm 0.06$ & $0.51 \pm 0.02$ & $0.41 \pm 0.02$ & $0.52 \pm 0.04$ \\
\hline $\mathrm{Cr}$ & $0.48 \pm 0.07$ & $0.44 \pm 0.07$ & $0.60 \pm 1$ & $0.60 \pm 0.08$ & $0.41 \pm 0.08$ & $0.50 \pm 0.06$ \\
\hline $\mathrm{Cu}$ & $100 \pm 12^{\mathbf{b}}$ & $455 \pm 21^{a}$ & $4208 \pm 410^{a}$ & $4442 \pm 436^{\mathbf{a}}$ & $2090 \pm 390^{\mathbf{a}}$ & $3207 \pm 278^{a}$ \\
\hline $\mathrm{Fe}$ & $439.45 \pm 66$ & $404.55 \pm 52$ & $468.29 \pm 54$ & $464.10 \pm 46$ & $354.33 \pm 72$ & $364.66 \pm 42$ \\
\hline Mn & $20.68 \pm 2.3$ & $15.35 \pm 1.71$ & $44.065 \pm 14$ & $22.72 \pm 2.24$ & $27.04 \pm 10.6$ & $23.03 \pm 3.88$ \\
\hline $\mathrm{Ni}$ & $0.893 \pm 0.28$ & $0.68 \pm 0.18$ & $0.55 \pm 0.16$ & $0.53 \pm 0.07$ & $0.41 \pm 0.1$ & $0.66 \pm 0.13$ \\
\hline $\mathrm{Pb}$ & $1.63 \pm 0.11$ & $2.23 \pm 0.15$ & $2.12 \pm 0.15$ & $2.19 \pm 0.2$ & $1.65 \pm 0.27$ & $2.05 \pm 0.16$ \\
\hline $\mathrm{Se}$ & $6.31 \pm 0.38$ & $5.17 \pm 0.28$ & $5.61 \pm 0.42$ & $6.69 \pm 0.41$ & $5.94 \pm 0.78$ & $6.31 \pm 0.68$ \\
\hline V & $1.14 \pm 0.10$ & $0.78 \pm 0.11$ & $1.53 \pm 0.25$ & $1.33 \pm 0.13$ & $1.34 \pm 0.13$ & $1.64 \pm 0.21$ \\
\hline $\mathrm{Zn}$ & $1485 \pm 260^{\mathbf{b}}$ & $2443 \pm 143$ & $6637 \pm 785^{a}$ & $7228 \pm 539^{a}$ & $4163 \pm 715^{a}$ & $4066 \pm 314^{a}$ \\
\hline $\mathrm{Ag}$ & $6.52 \pm 0.57^{\mathbf{b}}$ & $12.80 \pm 1.25^{a}$ & $5.64 \pm 0.51$ & $4.33 \pm 0.56$ & $7.57 \pm 1.54$ & $8.92 \pm 0.77$ \\
\hline Sn & NA & $0.03 \pm 0.02$ & $0.10 \pm 0.02$ & $0.11 \pm 0.02$ & $0.071 \pm 0.01$ & $0.15 \pm 0.05$ \\
\hline
\end{tabular}


Table 2

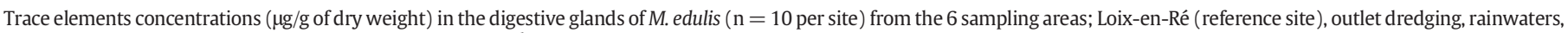
careening and fuels (now and old) areas. Different letters $\left({ }^{\mathbf{a}, \mathbf{b}}\right.$ ) above values indicate a significant difference where $p<0.05$.

\begin{tabular}{|c|c|c|c|c|c|c|}
\hline Tab. II & $\begin{array}{l}\text { Reference } \\
\text { Loix en Ré }\end{array}$ & $\begin{array}{l}\text { BDM } \\
\text { Outlet dredging }\end{array}$ & Outlet rainwaters & Careening area & Fuel area (now) & Fuel area (old) \\
\hline As & $34.25 \pm 1.38$ & $27.25 \pm 1.03$ & $21.20 \pm 0.38$ & $31.07 \pm 0.95$ & $22.32 \pm 1.41$ & $22.86 \pm 1.52$ \\
\hline $\mathrm{Cd}$ & $0.84 \pm 0.06$ & $1.32 \pm 0.09$ & $1.50 \pm 0.08$ & $1.13 \pm 0.08$ & $0.75 \pm 0.09$ & $1.63 \pm 0.06$ \\
\hline Co & $1.82 \pm 0.12^{\mathbf{b}}$ & $2.05 \pm 0.15$ & $1.06 \pm 0.19$ & $2.09 \pm 0.16^{\mathbf{a}}$ & $0.92 \pm 0.16$ & $1.45 \pm 0.21$ \\
\hline $\mathrm{Cr}$ & $3.36 \pm 0.30$ & $3.60 \pm 0.29$ & $3.15 \pm 0.66$ & $3.70 \pm 0.38$ & $2.68 \pm 0.99$ & $2.97 \pm 0.45$ \\
\hline $\mathrm{Cu}$ & $12.95 \pm 0.5^{\mathbf{b}}$ & $16.50 \pm 1$ & $81.71 \pm 8.17^{\mathbf{a}}$ & $96.67 \pm 17^{\mathbf{a}}$ & $23.01 \pm 4.12^{\mathrm{a}}$ & $19.63 \pm 2.31$ \\
\hline $\mathrm{Fe}$ & $2089 \pm 205$ & $2086 \pm 166$ & $1404 \pm 464$ & $1828 \pm 237$ & $925 \pm 197$ & $1698 \pm 371$ \\
\hline $\mathrm{Mn}$ & $51 \pm 4^{\mathbf{b}}$ & $67 \pm 6$ & $100 \pm 30^{\mathbf{a}}$ & $57 \pm 7$ & $28 \pm 4^{a}$ & $48 \pm 7$ \\
\hline $\mathrm{Ni}$ & $7.80 \pm 0.51^{\mathbf{b}}$ & $7.44 \pm 0.49$ & $3.15 \pm 0.70^{\mathbf{a}}$ & $7.09 \pm 0.44$ & $3.65 \pm 0.61$ & $4.90 \pm 0.60$ \\
\hline $\mathrm{Pb}$ & $4.44 \pm 0.36^{\mathbf{b}}$ & $5.89 \pm 0.50$ & $6.42 \pm 0.88^{a}$ & $4.60 \pm 0.51$ & $2.57 \pm 0.41^{\mathrm{a}}$ & $7.49 \pm 2.00^{\mathrm{a}}$ \\
\hline Se & $6.97 \pm 0.27^{\mathbf{b}}$ & $11.96 \pm 0.94^{\mathrm{a}}$ & $9.52 \pm 0.52$ & $9.51 \pm 0.23$ & $7.18 \pm 0.86$ & $7.27 \pm 0.70$ \\
\hline V & $4.57 \pm 0.43$ & $4.54 \pm 0.37$ & $3.87 \pm 1.04$ & $4.22 \pm 0.47$ & $2.43 \pm 0.37$ & $3.77 \pm 0.41$ \\
\hline $\mathrm{Zn}$ & $79 \pm 4^{b}$ & $98 \pm 5^{\mathbf{a}}$ & $268 \pm 18^{a}$ & $111 \pm 2^{\mathbf{a}}$ & $84 \pm 5$ & $174 \pm 70^{a}$ \\
\hline $\mathrm{Ag}$ & $0.13 \pm 0.02$ & $0.14 \pm 0.01$ & $0.14 \pm 0.02$ & $0.21 \pm 0.04$ & $0.07 \pm 0.01$ & $0.06 \pm 0.00$ \\
\hline Sn & $0.08 \pm 0.01$ & NA & $0.09 \pm 0.02$ & NA & $0.06 \pm 0.01$ & $0.08 \pm 0.01$ \\
\hline
\end{tabular}

Other trace elements did not show significant variation of concentrations between the control and impacted sites.

\subsection{Biochemical biomarker response}

Differences across species were apparent for four biomarkers assayed in the digestive gland of oysters, mussels and scallops. Biomarker data are summarised in Table 4.

\subsubsection{Superoxide dismutase activity}

The SOD activities in the digestive gland of $C$. gigas, $M$. edulis and $M$. varia are presented in Table 4. In Ré island, mean values were 25 and $29 \mathrm{U} / \mathrm{mg}$ of protein for oysters and mussels, respectively, and $58 \mathrm{U} / \mathrm{mg}$ of protein for the scallop. The SOD levels were higher for two sampling sites in outlet dredging and fuel (old) in the digestive glands of mussels. Conversely, a down-modulation was observed for oysters and scallops in fuel (old) and in careening area, respectively. Indeed, oysters and scallops from old fuel and careening areas showed $44 \%$ and $34 \%$ significantly lower specific activities when compared to the reference site, respectively. Moreover, a greater activity (approximately 46\%) of superoxide dismutase was measured in scallops collected in Ré island in comparison with oysters $C$. gigas and mussels M. edulis.

\subsubsection{Glutathione S-transferase activity}

For C. gigas, GST activity in digestive glands of Ré island showed an average value of $2.8 \pm 0.5 \mathrm{mU} / \mathrm{mg}$ of protein. For this species, no significant difference in GST specific activity was observed between the reference site and impacted sites. Concerning M. edulis, there was significantly more GST activity in the old fuel area than in Ré Island (Loix-en-Ré), the reference site. Regarding the third species, M. varia, a significant difference of specific activities was observed between four sampling areas (outlet dredging, rainwaters, careening, fuel (now): approximately 18,2\% higher) and the reference site. Moreover, there was a large difference in specific activities in the digestive glands of scallops (approximately 99\% higher) compared to oysters and mussels.

\subsubsection{Lipid peroxidation activity}

MDA content showed average values of $3.2 \pm 0.3,11 \pm 1.6$ and $3.2 \pm 0.2 \mu \mathrm{M} / \mathrm{mg}$ of proteins for oysters, mussels and scallops, respectively in the reference site Loix-en-Ré on Ré island. Firstly, for C. gigas, all sampling inside the harbour (rainwaters, careening, fuel now, fuel old) showed significantly higher MDA contents compared to the reference site. Secondly, our data showed significantly greater MDA contents in mussels sampled in outlet dredging (BDM) and both fuel areas. Finally, concerning the scallop species, a significantly lower activity was observed in the old fuel area compared to Ré island. Overall, $M$. edulis had a $70 \%$ higher response of this biomarker in its digestive gland in comparison with the other species.

\subsubsection{Laccase activity}

The mean Laccase activities in the digestive gland of $C$. gigas, $M$. edulis and $M$. varia were $2.13 \pm 0.12,0.57 \pm 0.01$ and $0.57 \pm$ $0.04 \mathrm{U} / \mathrm{mg}$ of protein in Loix-en-Ré the reference site, respectively. A higher response of this enzyme in the oyster species $C$. gigas was observed. Laccase activity in the digestive gland of $C$. gigas was

Table 3

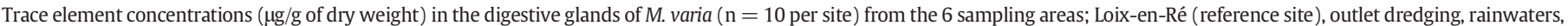
careening and fuels (now and old) areas. Different letters $\left({ }^{\mathbf{a}, \mathbf{b}}\right)$ above values indicate a significant difference where $p<0.05$.

\begin{tabular}{|c|c|c|c|c|c|c|}
\hline Tab. III & $\begin{array}{l}\text { Reference } \\
\text { Loix en Ré }\end{array}$ & $\begin{array}{l}\text { BDM } \\
\text { Outlet dredging }\end{array}$ & Outlet rainwaters & Careening area & Fuel area (now) & Fuel area (old) \\
\hline As & $19.33 \pm 0.95$ & $14.21 \pm 0.96$ & $19.04 \pm 1.60$ & $16.72 \pm 1.45$ & $17.55 \pm 1.67$ & $13.73 \pm 1.01$ \\
\hline $\mathrm{Cd}$ & $39.85 \pm 6.23^{\mathbf{b}}$ & $47.35 \pm 8.65$ & $11.85 \pm 2.34^{\mathbf{a}}$ & $14.34 \pm 1.61^{a}$ & $16.60 \pm 2.41^{\mathbf{a}}$ & $10.77 \pm 2.17^{a}$ \\
\hline Co & $1.51 \pm 0.13$ & $1.13 \pm 0.16$ & $1.81 \pm 0.22$ & $1.90 \pm 0.32$ & $1.37 \pm 0.19$ & $1.23 \pm 0.17$ \\
\hline $\mathrm{Cr}$ & $1.59 \pm 0.18$ & $1.89 \pm 0.21$ & $3.51 \pm 0.66$ & $2.67 \pm 0.37$ & $2.37 \pm 0.35$ & $1.98 \pm 0.25$ \\
\hline $\mathrm{Cu}$ & $41 \pm 7^{\mathbf{b}}$ & $73 \pm 20^{\mathbf{a}}$ & $556 \pm 61^{\mathbf{a}}$ & $503 \pm 88^{a}$ & $218 \pm 36^{\mathbf{a}}$ & $194 \pm 35^{\mathbf{a}}$ \\
\hline $\mathrm{Fe}$ & $694 \pm 72^{\mathbf{b}}$ & $656 \pm 79$ & $923 \pm 171^{a}$ & $878 \pm 127^{a}$ & $1174 \pm 211^{\mathbf{a}}$ & $919 \pm 230^{\mathbf{a}}$ \\
\hline $\mathrm{Mn}$ & $15.76 \pm 1.36^{\mathbf{b}}$ & $26.69 \pm 10.15^{\mathbf{a}}$ & $38.95 \pm 9.6^{\mathbf{a}}$ & $23.68 \pm 4.16^{\mathbf{a}}$ & $45.84 \pm 12.75^{\mathbf{a}}$ & $23.34 \pm 3.34^{a}$ \\
\hline $\mathrm{Ni}$ & $2.99 \pm 0.41$ & $2.16 \pm 0.31$ & $3.67 \pm 0.56$ & $3.53 \pm 0.58$ & $3.82 \pm 0.74$ & $2.80 \pm 0.46$ \\
\hline $\mathrm{Pb}$ & $2.20 \pm 0.14$ & $2.77 \pm 0.28$ & $2.15 \pm 0.34$ & $2.07 \pm 0.29$ & $2.68 \pm 0.43$ & $2.16 \pm 0.26$ \\
\hline $\mathrm{Se}$ & $10.58 \pm 0.38$ & $10.70 \pm 1.21$ & $12.39 \pm 1.23$ & $10.24 \pm 0.71$ & $11.64 \pm 1.18$ & $10.05 \pm 1.22$ \\
\hline V & $3.13 \pm 0.23$ & $2.51 \pm 0.33$ & $4.49 \pm 0.7$ & $4.67 \pm 0.75$ & $3.78 \pm 0.55$ & $4.20 \pm 0.52$ \\
\hline $\mathrm{Zn}$ & $114 \pm 23^{\mathbf{b}}$ & $144 \pm 30$ & $165 \pm 31^{a}$ & $102 \pm 10$ & $120 \pm 18$ & $74 \pm 8^{\mathbf{a}}$ \\
\hline $\mathrm{Ag}$ & $10.52 \pm 1.03$ & $10.21 \pm 1.03$ & $9.48 \pm 1.26$ & $6.69 \pm 1.13$ & $6.29 \pm 1.23$ & $4.60 \pm 0.81$ \\
\hline Sn & $0.04 \pm 0.00$ & $0.08 \pm 0.02$ & $0.15 \pm 0.02$ & $0.29 \pm 0.04$ & $0.09 \pm 0.01$ & $0.17 \pm 0.02$ \\
\hline
\end{tabular}


Table 4

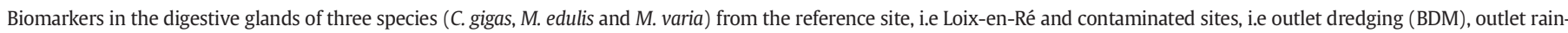
waters, careening area, fuel (now) and fuel (old) in January 2015. Data are expressed as mean $\pm \operatorname{sem}(\mathrm{n}=10)$.

\begin{tabular}{|c|c|c|c|c|c|c|c|c|}
\hline Biomarkers & & Species & $\begin{array}{l}\text { Loix-en-Ré } \\
\text { Reference }\end{array}$ & $\begin{array}{l}\text { BDM(Outlet } \\
\text { dredging) }\end{array}$ & $\begin{array}{l}\text { Outlet } \\
\text { rainwaters }\end{array}$ & Careening area & $\begin{array}{l}\text { Fuel } \\
\text { (now) }\end{array}$ & $\begin{array}{l}\text { Fuel } \\
\text { (old) }\end{array}$ \\
\hline \multirow[t]{6}{*}{ Defence } & $\begin{array}{l}\text { Superoxide } \\
\text { dismutase }\end{array}$ & $\begin{array}{l}\text { C. gigas } \\
\text { (oysters) }\end{array}$ & $25.2 \pm 2.0^{\mathrm{a}}$ & $23.6 \pm 1.7$ & $28.2 \pm 8.8$ & $28.5 \pm 4.5$ & $30.8 \pm 4.8$ & $14.1 \pm 2.1^{* * *}$ \\
\hline & (U.mg prot ${ }^{-1}$ ) & $\begin{array}{l}\text { M. edulis } \\
\text { (mussels) }\end{array}$ & $29.3 \pm 4.2^{\mathrm{a}}$ & $39.1 \pm 6.8^{* * *}$ & - & $21.3 \pm 6.6$ & $26.1 \pm 9.0$ & $42.7 \pm 7.4^{* * *}$ \\
\hline & & $\begin{array}{l}\text { M. varia } \\
\text { (scallop) }\end{array}$ & $58.0 \pm 2.8^{\mathrm{b}}$ & $56 \pm 3.6$ & $51.0 \pm 4.0$ & $38.0 \pm 5.0^{* * *}$ & $60.0 \pm 5.0$ & $59.0 \pm 5.0$ \\
\hline & $\begin{array}{l}\text { Glutathion } \\
\text { S-transferase }\end{array}$ & $\begin{array}{l}\text { C. gigas } \\
\text { (oysters) }\end{array}$ & $2.8 \pm 0.5^{\mathrm{a}}$ & $3.9 \pm 1.0$ & $1.6 \pm 0.4$ & $1.1 \pm 0.5$ & $1.8 \pm 0.4$ & $2.1 \pm 0.3$ \\
\hline & $\left(\mathrm{mU} . \mathrm{mg}\right.$ prot $\left.^{-1}\right)$ & $\begin{array}{l}\text { M. edulis } \\
\text { (mussels) }\end{array}$ & $7.7 \pm 0.4^{\mathrm{a}}$ & $7.8 \pm 1.5$ & - & $7.6 \pm 0.5$ & $6.3 \pm 0.5$ & $9.7 \pm 1.0^{*}$ \\
\hline & & $\begin{array}{l}\text { M. varia } \\
\text { (scallop) }\end{array}$ & $1070 \pm 167^{\mathrm{b}}$ & $1370 \pm 165^{* * *}$ & $1397 \pm 64^{* * *}$ & $1282 \pm 103^{* * * *}$ & $1207 \pm 94^{* * *}$ & $1026 \pm 97$ \\
\hline \multirow[t]{3}{*}{$\begin{array}{l}\text { Lipidic } \\
\text { Peroxidation }\end{array}$} & $\begin{array}{l}\text { Malondialdehyde } \\
\left(\mu \mathrm{M} . \mathrm{mg} \mathrm{prot}^{-1}\right)\end{array}$ & $\begin{array}{l}\text { C. gigas } \\
\text { (oysters) }\end{array}$ & $3.2 \pm 0.3^{\mathrm{a}}$ & $5.4 \pm 0.3$ & $23.7 \pm 15^{*}$ & $8.9 \pm 0.8^{*}$ & $7 \pm 1.8^{*}$ & $8.7 \pm 1.2^{*}$ \\
\hline & & $\begin{array}{l}\text { M. edulis } \\
\text { (mussels) }\end{array}$ & $11 \pm 1.6^{b}$ & $14.6 \pm 1.7^{*}$ & - & $13.0 \pm 0.9$ & $19.5 \pm 5^{* *}$ & $26.3 \pm 3.9^{* * *}$ \\
\hline & & $\begin{array}{l}\text { M. varia } \\
\text { (scallop) }\end{array}$ & $3.2 \pm 0.2^{\mathrm{a}}$ & $3.3 \pm 0.2$ & $4.0 \pm 0.4$ & $4.6 \pm 0.5$ & $2.9 \pm 0.2$ & $1.9 \pm 0.1^{*}$ \\
\hline \multirow[t]{3}{*}{ Immuno-modulation } & $\begin{array}{l}\text { Laccase } \\
\left(\text { U.mg prot }^{-1}\right)\end{array}$ & $\begin{array}{l}\text { C. gigas } \\
\text { (oysters) }\end{array}$ & $2.13 \pm 0.12^{b}$ & $1.06 \pm 0.07^{* *}$ & $1.57 \pm 0.13^{*}$ & $1.54 \pm 0.11^{*}$ & $2.04 \pm 0.13$ & $1.74 \pm 0.11$ \\
\hline & & $\begin{array}{l}\text { M. edulis } \\
\text { (mussels) }\end{array}$ & $0.57 \pm 0.01^{a}$ & $0.39 \pm 0.01^{*}$ & - & $1.30 \pm 0.06^{* * *}$ & $1.07 \pm 0.06^{* * *}$ & $1.00 \pm 0.06^{* *}$ \\
\hline & & $\begin{array}{l}\text { M. varia } \\
\text { (scallop) }\end{array}$ & $0.57 \pm 0.04^{\mathrm{a}}$ & $0.65 \pm 0.05^{*}$ & $0.47 \pm 0.02$ & $0.63 \pm 0.04^{*}$ & $0.76 \pm 0.03^{*}$ & $0.90 \pm 0.05^{* *}$ \\
\hline
\end{tabular}

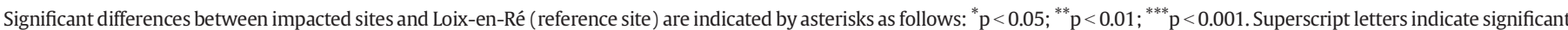
$(\mathrm{p}<0.05)$ differences among species in Loix-en-Ré (reference site).

significantly lower in the outlet dredging, rainwater and careening areas in comparison with the reference site. On the contrary, data from the scallop species showed a significantly greater modulation of specific activity in digestive glands from outlet dredging, careening, and fuel (now and old) areas. Concerning M. edulis, we noted significantly lower Laccase activities for mussels from outlet dredging and significantly higher activities for mussels in the careening and fuel areas compared to the reference site.

\subsection{Correlations between biomarker responses and trace element concentrations}

A multi-correlation (Table 5) test was conducted between trace elements concentrations and biomarkers values. It revealed for oysters: (i) significant correlations of SOD activity with $\mathrm{Cd}, \mathrm{Cu}, \mathrm{Mn}, \mathrm{Pb}$ and $\mathrm{Sn}$; (ii) no correlation of GST activity with any of the considered trace elements; (iii) significant correlations of MDA with $\mathrm{Cd}, \mathrm{Cu}, \mathrm{Zn}, \mathrm{Ag}$ and $\mathrm{Sn}$; (iv) significant correlations of laccase with $\mathrm{Pb}, \mathrm{Fe}$ and $\mathrm{Ag}$.
It revealed for mussels: (i) no correlation of SOD activity with any of the trace elements; (ii) a low correlation for GST and MDA activities with As and Ag, respectively; (iii) significant correlations of laccase with $\mathrm{Co}, \mathrm{Cu}, \mathrm{Fe}, \mathrm{Ni}$ and $\mathrm{V}$.

It revealed for scallops: (i) significant correlations of SOD with $\mathrm{Cd}$, $\mathrm{Cu}, \mathrm{Pb}, \mathrm{Ag}$ and $\mathrm{Sn}$; (ii) significant differences of GST with $\mathrm{Cu}$ and $\mathrm{Zn}$; (iii) significant correlations of MDA with As, Zn and Ag; (iv) significant correlations of Laccase with $\mathrm{Zn}$ and $\mathrm{Ag}$.

\subsection{Genetic approach}

We obtained good quality sequences for 30 scallops (486-499 bp), 22 mussels (464-477 bp) and 25 oysters (630-638 bp). Aligning all sequences for each species revealed: six substitutions in scallops, nine in mussels and 10 in oysters. For cox 1 sequences, all substitutions were synonymous.

Sequences obtained from scallops all closely matched (97-98\% sequence similarity) Mimachlamys varia cox1 sequences in Genbank (Table S3, supplementary data; note that sequences from Breitwieser

Table 5

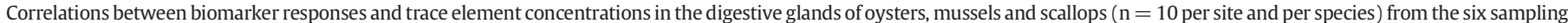

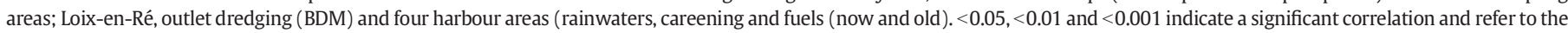
p-value - indicates no significant correlation. GST: Glutathione S-transferase; SOD: superoxide dismutase; MDA: malondialdehyde

\begin{tabular}{|c|c|c|c|c|c|c|c|c|c|c|c|c|c|c|}
\hline Oysters & $S O D$ & GST & $M D A$ & Laccase & Mussels & $S O D$ & GST & $M D A$ & Laccase & Scallops & $S O D$ & GST & $M D A$ & Laccase \\
\hline As & - & - & - & - & As & - & $<0.05$ & - & - & As & - & - & $<0.05$ & - \\
\hline Cd & $<0.01$ & - & $<0.05$ & - & $C d$ & - & - & - & - & $C d$ & $<0.01$ & - & - & - \\
\hline Co & - & - & - & - & Co & - & - & - & $<0.05$ & Co & - & - & - & - \\
\hline $\mathrm{Cr}$ & - & - & - & - & $\mathrm{Cr}$ & - & - & - & - & $\mathrm{Cr}$ & - & - & - & - \\
\hline $\mathrm{Cu}$ & $<0.01$ & - & $<0.01$ & - & $\mathrm{Cu}$ & - & - & - & $<0.01$ & $\mathrm{Cu}$ & $<0.01$ & $<0.05$ & - & - \\
\hline $\mathrm{Fe}$ & - & - & - & $<0.01$ & $\mathrm{Fe}$ & - & - & - & $<0.01$ & $\mathrm{Fe}$ & - & - & - & - \\
\hline$M n$ & $<0.01$ & - & - & - & $M n$ & - & - & - & - & $M n$ & - & - & - & - \\
\hline $\mathrm{Ni}$ & - & - & - & - & $\mathrm{Ni}$ & - & - & - & $<0.01$ & $\mathrm{Ni}$ & - & - & - & - \\
\hline$P b$ & $<0.05$ & - & - & $<0.01$ & $P b$ & - & - & - & - & $P b$ & $<0.01$ & - & - & - \\
\hline Se & - & - & - & - & Se & - & - & - & - & Se & - & - & - & - \\
\hline $\boldsymbol{V}$ & - & - & - & - & $V$ & - & - & - & $<0.05$ & $V$ & - & - & - & - \\
\hline$Z n$ & - & - & $<0.01$ & - & $Z n$ & - & - & - & - & $Z n$ & - & $<0.05$ & $<0.05$ & $<0.05$ \\
\hline Ag & - & - & $<0.01$ & $<0.01$ & Ag & - & - & $<0.05$ & - & $\mathrm{Ag}$ & $<0.01$ & - & $<0.05$ & $<0.01$ \\
\hline Sn & $<0.01$ & - & $<0.05$ & - & Sn & - & - & - & - & Sn & $<0.01$ & - & - & - \\
\hline
\end{tabular}


et al. (2016) were not used in this comparison). A total of seven haplotypes were sampled in scallops (not taking into account two sequences with uncertainties, i.e., with ambiguous bases). Among these scallop haplotypes, two were previously detected in this geographic area, including one that was the most common haplotype in Breitwieser et al. (2016).

Sequences obtained for oysters all closely matched (99-100\% sequence similarity) Crassostrea gigas cox1 sequences in Genbank (Supplementary Table S3). Mitochondrial 16S rDNA sequences obtained from mussels were identical or closely matched sequences from individuals in the Mytilus edulis-galloprovincialis-trossulus complex. In some cases, our sequences were identical to records corresponding to several species. The Mytilus spp. alignment used to construct the NJ tree included 33 unique 16S rDNA haplotypes. Our sequences did not fall within the well-supported $M$. trossulus clade or in the supported M. galloprovincialis clade identified in Gerard et al. (2008) (Fig. 3). The mussel haplotypes we observed were either identical to sequences identified as M. edulis or were within the unresolved portion of the tree, similarly to other $M$. edulis sequences analyzed in Gerard et al. (2008).

\section{Discussion}

\subsection{Trace elements}

Contamination levels were estimated in three marine bivalve species (oyster $C$. gigas, mussel M. edulis, scallop M. varia) by assessing the trace element concentrations in their digestive glands. In coastal waters, bioaccumulated contaminants are considered as valuable tracers of habitat quality and need to be monitored in living species.

Many scientific investigations conducted on the bioaccumulation capacity of mollusks have been performed in controlled conditions of contamination, while our study was carried out using bivalves sampled in situ. In oysters, our results showed higher concentrations of $\mathrm{Zn}$ and $\mathrm{Cu}$ in the harbour area (rainwater, careening, fuels areas) and in outlet dredging site in comparison with the reference site Loix-en-Ré. Moreover, Ag concentrations in the outlet dredging, which is outside the harbour, was higher than in the reference site. These results support a hypothesis of environmental contamination generated by alloying agents used in roadworks and roofing panels.

Concerning mussels, this species accumulated more $\mathrm{Cu}$ in the outlet rainwater, $\mathrm{Co}$ in the careening area and $\mathrm{Zn}$ in the outlet rainwater and fuel station in accordance with previous results (Tacon and Metian, 2008), and this bioaccumulation could cause a health risk for consumers of bivalves (Metian et al., 2008). Moreover, digestive glands of the scallop species M. varia had elevated concentrations of $\mathrm{Cu}$ and Fe for all sites in the harbour and of $\mathrm{Mn}$ (fuel station) in comparison with the reference site. Indeed, their use in antifouling paints could explain higher concentrations of essential metals, which could be toxic in excessive concentrations (Bustamante and Miramand, 2005).

Compared to oysters and mussels that filter contaminants associated with particles suspended in the water column, scallops live at the water-sediment interface and are likely more impacted by contaminants in the sediments than the other two bivalves. Routine measurements of trace element concentrations in the sediment conducted by the harbour of La Rochelle do indicate a high bioavailability of some inorganic contaminants in the sediment of two stations within the harbour (Table S1, supplementary data).

Overall, these analyses showed that sessile organisms found at different sites within the Marina display high concentrations of some inorganic elements, which suggests a chronic chemical contamination in the La Rochelle harbour. This can be explained by a lot of boat careening (dirt-resistance paint against biofouling) and a strong recreational boating activity. Indeed, several studies have shown that dredging or

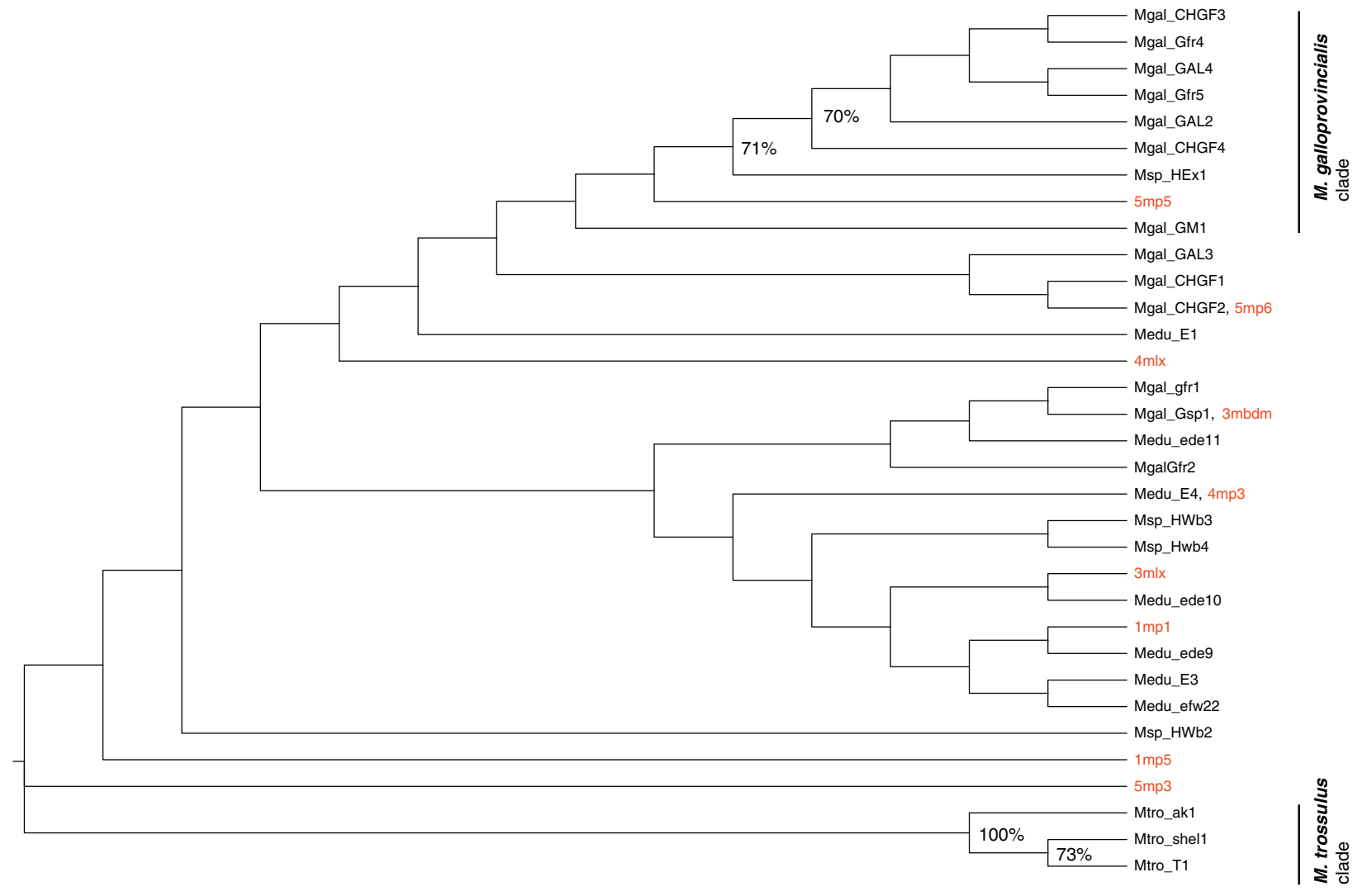

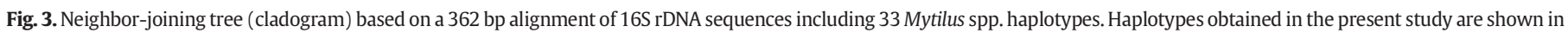
red. Bootstrap support values above $70 \%$ appear right of the node. 
sediment suspension in harbour areas has affected aquatic fauna and the marine ecosystem by organic and inorganic contamination (Steger and Gardner, 2007; Magni et al., 2008; Jane et al., 2010; Sundstein et al., 2010; Kolarević et al., 2016; Chan et al., 2016).

Taken together, results from previous reports and in our study show significant anthropogenic impacts on the coastal environment of La Rochelle. Indeed, a large number of human activities are concentrated on few kilometres of coast in this region (fishing harbour, petroleum refinery, public treatment plant), in addition to a yacht harbour. High concentrations of trace elements in the digestive gland of scallops, oysters and mussels could be explained by sewage in the coastal waters of the harbour. Such findings suggest the need to frequently monitor the harbour of La Rochelle, and to evaluate the potential biological effects of this contamination through enzymes of the toxicity response like in a previous report of Laitano et al. (2016).

Furthermore, capacities for inorganic contaminants bioaccumulation in bivalve mollusks (Bryan, 1973) depend on the main characteristics of each organ such as trapping nutrients (gills), or digesting and excreting nutrients (digestive gland). Our study focused on the digestive gland, however it is important to underline other bioaccumulating organs that would be of interest such as the kidney of oysters, mussels and scallops, mostly for non-essential metals, which could be toxic for the organism, in particular at the cellular scale.

\subsection{Biomarkers}

Biomarkers of oxidative stress were measured in three species ( $C$. gigas, M. edulis and M. varia) from five impacted sites (four harbour areas and outlet dredging) and the reference site, Loix-en-Ré.

The biomarker SOD was assessed because it intervenes at an early stage of oxidative stress before cellular damage (Valavanidis et al., 2006). The specific activity of SOD in individuals from the harbour areas (careening and fuel, now and old) in comparison with those of Loix-en-Ré is different among the three species; our results have showed a positive modulation of the enzymatic activity for mussels and negative modulation for oysters and scallop. Negative modulations of SOD in oyster and scallops are in disagreement with previous studies (Breitwieser et al., 2016; Milinkovitch et al., 2015; Luna-Acosta et al., 2015; Luna-Acosta et al., 2011; Pan et al., 2005), and are opposite to results of SOD specific activity level in mussels. Measuring the enzymatic activity of SOD revealed significantly lower activity for the scallop $M$. varia in the careening area within the harbour compared to the reference site. Thus, factors other than the level in the foreshore are likely to affect biomarker in the present study. Indeed, these results could be due to the effect of abiotic factors on the concentration of heavy metals in organs, which interfere with essential elements.

Another biomarker, Glutathione S-transferase activity showed higher responses (about 99\%) in scallops in comparison with the other two sampled bivalve species, in agreement with a previous study highlighting significant responses of this enzyme in $M$. varia (Breitwieser et al., 2016). GST is involved in the detoxification mechanisms of xenobiotics in suspension or in the mud. The scallop M. varia lives in a supra-benthic situation near mudflats and potentially contaminated sediment. The latter point could explain the strong response of this enzyme implicated in detoxification of xenobiotics. Higher cellular oxidant system activities of the GST enzyme are in accordance with the results of Borković et al. (2005).

Lipid peroxidation in the scallop M. varia was evaluated with MDA concentrations, which ranged between 3.2 and $4.6 \mu \mathrm{M} / \mathrm{mg}$ of proteins (reference site and careening, respectively).

The concentration of MDA in the digestive gland of marine organisms reflects an activation of lipid peroxidation in cell membranes. MDA concentrations were significantly higher in the digestive gland of the mussel species $M$. edulis from both fuel stations in comparison with the reference site Loix-en-Ré and therefore a heavy metal contaminated area (fuel); it is hypothesized that this response could be due to hydrocarbon contamination in this species. In the scallop species $M$. varia, an increased response was observed in the careening area for SOD but not for MDA. This last finding could be explained by an activation of the first mechanism of defence against oxidative stress, which occurs before lipid peroxidation, in accordance with previous work of Liu et al. (2012). In scallops, MDA content was indeed significantly lower in the old fuel area in comparison with the reference site. For this species, MDA contents may be a better biomarker of acute and strong contamination, than of lower and chronic chemical pollution. These MDA concentrations are the result of oxidative stress due to polyunsaturated fat oxidation by superoxide ion (principal product). In this way, the more superoxide ions are in the cells of organisms, the higher MDA quantity there will be. Lipid peroxidation is the last line of defence because phospholipids will trap a large part of the reactive oxygen species before a potential protein impact occurs.

We show that the three species are sensitive to pollutants in the harbour area, and an immune system alteration was suggested by the laccase assay study. Indeed, according to previous studies by Luna-Acosta et al. (2011 and 2015) in C. gigas, laccase activity may be triggered by an activation of protection against contaminant bioaccumulation. However, in this project, laccase specific activity in oysters was negatively altered in outlet dredging (BDM), rainwaters and careening areas, not in agreement with the previous study of LunaAcosta et al. (2015). These differences could be due to abiotic factors (water and air temperature) because this species lives high up in the piling dock of the harbour. Response of this immune enzyme was lower in mussels and scallops, in comparison with oysters. However, positive significant results were obtained in particular for the scallop in outlet dredging, careening and both fuel areas. These results also indicate a modulation of enzymatic activity by contaminants (hydrocarbons, pesticides), which generate an increase in ROS in accordance with previous report in this species (Milinkovitch et al., 2015; Breitwieser et al., 2016).

Species variation in biomarker activity or content may be due to differences in the vertical level (and thus time of air exposure) of oysters, mussels and scallops in the foreshore. Moreover, abiotic factors such as salinity, dissolved oxygen, nutrients, and chlorophyll, as well as the sampling date and time, could also play an important role. Indeed, our sampling (in January) was conducted at a time of organism weightloss, when perhaps less energy can be allocated to defence mechanisms (Schmidt et al., 2013).

\subsection{Correlations}

Statistic correlation tests were carried out to investigate relationships between inorganic pollutants and specific activity of biomarkers in order to determine the best bioindicator species for longer-term studies in the La Rochelle harbour. Indeed, it now seems necessary to bridge both, bioaccumulation and enzymatic data, which have not been covered together in previous reports on bivalve species in harbours (Caro et al., 2015; Hussein and Khaled, 2014; Walker and MacAskill, 2014; Jebali et al., 2014; Conte et al., 2015; Jitar et al., 2015; Walker and Grant, 2015).

Pollutant concentrations in the digestive gland of these three species were shown to correlate with biomarker responses (MDA, SOD, GST and laccase), but several natural abiotic factors (oxygen level, temperature, salinity and the chemical environment) could also explain the modulation of oxidative stress, as well as immunological parameters in aquatic organisms. Moreover, only the laccase biomarker was impacted by the majority of heavy metals ( $\mathrm{Co}, \mathrm{Cu}, \mathrm{Fe}, \mathrm{Ni}, \mathrm{V}, \mathrm{Pb}, \mathrm{Ag}$ and $\mathrm{Zn}$ ).

Concerning the scallop, $M$. varia was the most sensitive species showing pollution modulation of the four enzymes, which suggests that mussels and oysters would not always be the best bioindicator bivalves among marine invertebrates depending on the responses that are assessed. Indeed, all biomarkers (SOD, GST, MDA and laccase) showed correlations with $\mathrm{Ag}, \mathrm{As}, \mathrm{Cu}, \mathrm{Zn}, \mathrm{Cd}, \mathrm{Pb}$ and $\mathrm{Sn}$. These results 
suggest that oxidative stress could be due to (i) oligo elements consequent to bioaccumulation, and/or (ii) water contamination in the La Rochelle harbour area.

Even though there were correlations between inorganic contaminants and biomarkers, it is crucial to acknowledge other in situ parameters, such as abiotic factors (dissolved oxygen, temperature, $\mathrm{pH}$, salinity), which could modulate oxidative stress and death induction of cell in aquatic organisms (Lushchak, 2011). Additionally, other contaminants not measured here may be present in high concentrations in certain areas of a harbour such as PAHs near fueling stations. Thus, the biomarker modulation we observed likely reflects responses to a mixture of contaminants.

\subsection{Species identifications through DNA barcoding}

Using a DNA barcoding approach, we validated species identifications made in the field by combining two lineage identification tools: a BLAST search in Genbank and a phylogenetic tree including sequences from previous studies. Based on the high sequence similarity between our haplotypes and sequences in Genbank for the three bivalves, we could discount the presence of cryptic lineages that could potentially bias our contaminant and biomarker data. The BLAST results we obtained for mussels stem from the hybridization history known in the Mytilus species complex. For instance, the mitochondrial genome of $M$. edulis has been captured (through introgression) in some M. trossulus populations in the Baltic Sea (e.g. Kijewski et al., 2006). Thus, some mussel sequences labeled $M$. trossulus in Genbank may actually correspond to $M$. edulis haplotypes, which explains our BLAST results. Despite their history of hybridization, the three entities ( $M$. trossulus, $M$. edulis and $M$. galloprovincialis) are still considered as separate species, but show different levels of introgression along their European distribution (e.g. Bierne et al., 2003).

Our molecular species identification was based on a single mitochondrial DNA locus and we could therefore not rule out the presence of individuals with a hybrid genetic background. Nuclear markers would be necessary to assess hybrid status of these mussel individuals, which was beyond the scope of the present study. Findings from a recent ecotoxicological study conducted on the Mytilus spp. complex support the need to determine the genetic background of mussels in biomonitoring studies. Indeed, Brooks et al. (2015) revealed differences in contaminant bioaccumulation and biomarker responses among Mytilus species (Brooks et al., 2015). Given the hybridization history of mussels and results from Brooks et al. (2015), interpretation of biomonitoring data conducted on mussel samples collected in situ should be made with caution unless the genetic background of sampled individuals is assessed.

\section{Conclusion}

After qualifying for the ISO 14001 Ecomanagement certification, the La Rochelle Marina has contributed to environmental protection and to user awareness in this area. The harbour management works to reduce contaminant concentrations, in particular with a careening water treatment system that was installed two years ago, together with a new fuelling station that limits hydrocarbon leaks and provides a better containment of drips.

Our results indicate significant multi-biomarker responses to trace metal contamination in the digestive glands of variegated scallops, which therefore might be used as a sensitive bioindicator species to address questions on environmental issues in harbour ecosystems.

\section{Funding}

Port de Plaisance de La Rochelle, University of La Rochelle and Centre National Recherche Scientifique (France).

\section{Acknowledgements}

A Master grant from the Harbour of La Rochelle supported this study for Marine Breitwieser. The authors thank the people involved in sampling: A. Combaud, T. Guyot, A. Bonnet, V. Becquet and P. Pelletant, as well as B. Simon-Bouhet for his scientific advice and help in statistical analyses. We would like to acknowledge Célia Fery for performing some biomarker assays.

\section{Appendix A. Supplementary data}

Supplementary data to this article can be found online at http://dx. doi.org/10.1016/j.cbpc.2017.02.006.

\section{References}

Bakary, I.A., Yao, K.M.A., Etchian, O.A.B., Soro, M.B.A., Trokourey, A.C., Bokra, Y.C., 2015. Zinc, copper, cadmium, and lead concentrations in water, sediment, and Anadara senilis in a tropical estuary. Environ. Monit. Assess. 187 (12), 1-11.

Bierne, N., Borsa, P., Daguin, C., Jollivet, D., Viard, F., Bonhomme, F., David, P., 2003. Introgression patterns in the mosaic hybrid zone between Mytilus edulis and $M$. galloprovincialis. Mol. Ecol. 12, 447-461.

Borković, S.S., Šaponjić, J.S., Pavlović, S.Z., Blagojević, D.P., Milošević, S.M., Kovačević, T.M., Radojičić, R.M., Spasić, M.B., Žikić, R.V., Saičić, Z.S., 2005. The activity of antioxidant defence enzymes in the mussel Mytilus galloprovincialis from the Adriatic Sea. Comp. Biochem. Physiol. C Toxicol. Pharmacol. 141 (4), 366-374.

Breitwieser, M., Viricel, A., Graber, M., Murillo, L., Becquet, V., Churlaud, C., FruitierArnaudin, I., Huet, V., Lacroix, C., Pante, E., Le Floch, S., Thomas-Guyon, H., 2016. Short-term and long-term biological effects of chronic chemical contamination on natural populations of a marine bivalve. PLOS ONE 11 (3), e0150184.

Brooks, S.J., Farmen, E., Heir, L.S., Blanco-Rayón, E., Izagirre, U., 2015. Differences in copper bioaccumulation and biological responses in three Mytilus species. Aquat. Toxicol. $160,1-12$.

Bryan, G.W., 1973. The occurrence and seasonal variation of trace metals in the scallops Pecten maximus (L.) and Chlamys opercularis (L.). J. Mar. Biol. Assoc. U. K. 53 (01), 145-166.

Bustamante, P., Miramand, P., 2005. Evaluation of the variegated scallop Chlamys varia as a biomonitor of temporal trends of $\mathrm{Cd}, \mathrm{Cu}$, and $\mathrm{Zn}$ in the field. Environ. Pollut. 138 (1), 109-120.

Caro, A., Chereau, G., Briant, N., Roques, C., Freydier, R., Delpoux, S., Escalas, A., ElbazPoulichet, F., 2015. Contrasted responses of Ruditapes decussatus (filter and deposit feeding) and Loripes lacteus (symbiotic) exposed to polymetallic contamination (Port-Camargue, France). Sci. Total Environ. 505, 526-534

Chan, J.T.K., Leung, H.M., Yue, P.Y.K., Au, C.K., Wong, Y.K., Cheung, K.C., Li, W.C., Yung, K.K.L., 2016. Combined effects of land reclamation, channel dredging upon the bioavailable concentration of polycyclic aromatic hydrocarbons (PAHs) in Victoria Harbour sediment, Hong Kong. Marine Pollution Bulletin 08030.

Conte, F.B., Copat, C.B., Longo, S.A., Oliveri Conti, G.B., Grasso, A.B., Arena, G.B., Brundo, M.V.C., Ferrante, M.B., 2015. First data on trace elements in Haliotis tuberculata (Linnaeus, 1758) from southern Italy: safety issues. Food Chem. Toxicol. 81, 143-150.

R Core Team, 2016. R: A Language and Environment for Statistical Computing. R Foundation for Statistical Computing, Vienna, Austria (ULR http://www.R-project.org/).

Feckler, A. Thielsch, A. Schwenk, K. Schulz, R., Bundschuh, M., 2012. Differences in the sensitivity among cryptic lineages of the Gammarus fossarum complex. Sci. Total Environ. 439, 158-164.

Folmer, O., Black, M., Hoeh, W., Lutz, R., Vrijenhoek, R., 1994. DNA primers for amplification of mitochondrial cytochrome c oxidase subunit I from diverse metazoan invertebrates. Mol. Mar. Biol. Biotechnol. 3, 294-299.

Gerard, K., Bierne, N., Borsa, P., Chenuil, A., Féral, J.-P., 2008. Pleistocene separation of mitochondrial lineages of Mytilus spp. mussels from northern and southern hemisphere and strong genetic differentiation among southern populations. Mol. Phylogenet. Evol. 49, 84-91.

Gerard-Monnier, D., Erdelmeier, I., Chaudiere, J., Yadan, J.C., 1998. Method of colorimetric analysis of malonic dialdehyde and 4-hydroxy-2-enaldehydes as indexes of lipid peroxidation, kits for carrying out said method, substituted indoles for use in said method and their preparation. US Patent No. US5726063. United States Patent and Trademark Office, Washington, DC.

Habig, W.H., Pabst, M.J., Jakoby, W.B., 1974. Glutathione S-transferases. The first enzymatic step in mercapturic acid formation. J. Biol. Chem. (edition, section 24).

Hussein, A., Khaled, A., 2014. Determination of metals in tuna species and bivalves from Alexandria, Egypt. Egypt. J. Aquat. Res. 40 (1), 9-17.

Jane, B.M., Coleman, M.A., Kelaher, B.P., 2010. Cross-habitat impacts of species decline: response of estuarine sediment communities to changing detrital resources. Oecologia 163, 517-525.

Jebali, J., Chouba, L., Banni, M., Boussetta, H., 2014. Comparative study of the bioaccumulation and elimination of trace metals ( $\mathrm{Cd}, \mathrm{Pb}, \mathrm{Zn}, \mathrm{Mn}$ and $\mathrm{Fe}$ ) in the digestive gland, gills and muscle of bivalve Pinna nobilis during a field transplant experiment. J. Trace Elem. Med. Biol. 28 (2), 212-217.

Jitar, O.A., Teodosiu, C.A., Oros, A.B., Plavan, G.C., Nicoara, M.C., 2015. Bioaccumulation of heavy metals in marine organisms from the. Rom. Sect. Black Sea New Biotechnol. 32 (3), 369-378. 
Kijewski, T.K., Zbawicka, M., Väinölä, R., Wenne, R., 2006. Introgression and mitochondrial DNA heteroplasmy in the Baltic populations of mussels Mytilus trossulus and M. edulis. Mar. Biol. 149, 1371-1385.

Kolarević, S., Kračun-Kolarević, M., Kostić, J., Slobodnik, J., Liška, I., Gačić, Z., Paunović, M., Knežević-Vukčević, J., Vuković-Gačić, B., 2016. Assessment of the genotoxic potential along the Danube River by application of the comet assay on haemocytes of freshwater mussels: the joint Danube survey. Sci. Total Environ. 540, 377-385.

Lacroix, C., Richard, G., Seguineau, C., Guyomarch, J., Moraga, D., Auffret, M., 2015. Active and passive biomonitoring suggest metabolic adaptation in blue mussels (Mytilus spp.) chronically exposed to a moderate contamination in Brest harbor (France). Aquat. Toxicol. 162, 126-137.

Laitano, M.V., Silva Barni, M.F., Costa, P.G., Cledón, M., Fillmann, G., Miglioranza, K.S.B., Panarello, H.O., 2016. Different carbon sources affect PCB accumulation by marine bivalves. Mar. Environ. Res. 113, 62-69.

Lam, P.K.S., 2009. Use of biomarkers in environmental monitoring. Ocean Coast. Manag. 52 (7), 348-354

Liu, N., Pan, L., Wang, J., Yang, H., Liu, D., 2012 Sep. Application of the biomarker responses in scallop (Chlamys far-reri) to assess metals and PAHs pollution in Jiaozhou Bay, China. Mar. Environ. Res. 80:38-45. http://dx.doi.org/10.1016/j.marenvres.2012.06. 008 PMID: 22784563.

Luna-Acosta, A., Bustamante, P., Budzinski, H., Huet, V., Thomas-Guyon, H., 2015 May 1. Persistent organic pollutants in a marine bivalve on the Marennes-Oléron Bay and the Gironde Estuary (French Atlantic Coast)-Part 2: Potential biological effects. Sci. Total Environ. 514:511-522. http://dx.doi.org/10.1016/j.scitotenv. 2014.10.050 PMID: 25666833.

Luna-Acosta, A., Rosenfeld, E., Amari, M., Fruitier-Arnaudin, I., Bustamante, P., ThomasGuyon, H., 2010. First evidence of laccase activity in the Pacific oyster Crassostrea gigas. Fish Shellfish Immunol. 28 (4), 719-726.

Luna-Acosta, A., Saulnier, D., Pommier, M., Haffner, P., De Decker, S., Renault, T., ThomasGuyon, H., 2011. First evidence of a potential antibacterial activity involving a laccasetype enzyme of the phenoloxidase system in Pacific oyster Crassostrea gigas haemocytes. Fish Shellfish Immunol. 31 (6), 795-800.

Lushchak, V.I., 2011. Environmentally induced oxidative stress in aquatic animals. Aquat. Toxicol. 101 (1), 13-30.

Magni, P., Rajagopal, S., Van der Velde, G., Fenzi, G., Kassenberg, J., Vizzini, S., Mazzola, A., Giordani, G., 2008. Sediment features, macrozoobenthic assemblages and trophic relationships (delta C-13 and delta N-15 analysis) following a dystrophic event with anoxia and sulphide development in the Santa Giusta lagoon (western Sardinia, Italy). Mar. Pollut. Bull. 57, 125-136.

Mannervik, B., Helena-Danielson, U., Ketterer, B., 1988. Glutathione transferases-structure and catalytic activity. Crit. Rev. Biochem. Mol. Biol. 23 (3), 283-337.

Metian, M., Bustamante, P., Hédouin, L., Warnau, M., 2008. Accumulation of nine metals and one metalloid in the tropical scallop Comptopallium radula from coral reefs in New Caledonia. Environ. Pollut. 152 (3), 543-552 (PMID: 17703858).

Milinkovitch, T., Bustamante, P., Huet, V., Reigner, A., Churlaud, C., Thomas-Guyon, H. 2015. In situ evaluation of oxidative stress and immunological parameters as ecotoxicological biomarkers in a novel sentinel species (Mimachlamys varia). Aquat. Toxicol. $161,170-175$

Paoletti, F., Aldinucci, D., Mocali, A., Caparrini, A., 1986. A sensitive spectrophoto-metric method for the determination of superoxide dismutase activity in tissue extracts. Anal. Biochem. 154 (2), 536-541 PMID: 3089061.
Palumbi, S.R., Martin, A.P., Romano, S., McMillan, W.O., Stice, L., Grabowski, G., 1991. The Simple Fool's Guide to PCR. Version 2.0. Department of Zoology, University of Hawaii, Honolulu.

Pan, L., Jiayun, R., Liu, J., 2005. Effects of benzo (k) fluoranthene exposure on the biomarkers of scallop Chlamys farreri. Comp. Biochem. Physiol. C Toxicol. Pharmacol. 141 (3), 248-256.

Pippy, B.A., Kidd, K.A., Munkittrick, K.R., Mercer, A., Hunt, H., 2016. Use of the Atlantic nut clam (Nucula proxima) and catworm (Nephtys incisa) in a sentinel species approach for monitoring the health of Bay of Fundy estuaries (2016). Mar. Pollut. Bull. 106 (1-2), 225-235.

Prohaska, J.R., 1980. The glutathione peroxidase activity of glutathione S-transferases. Biochim. Biophys. Acta, Enzymol. 611 (1), 87-98.

Schmidt, W., Power, E., Quinn, B., 2013. Seasonal variations of biomarker responses in the marine blue mussel (Mytilus spp.). Mar. Pollut. Bull. 74 (1), 50-55.

Smith, P.K, Krohn, R., Hermanson, G.T., Mallia, A.K., Gartner, F.H., Provenzano, M.D. Fujimoto, E.K., Goeke, N.M., Olson, B.J., Klenk, D.C., 1985. Measurement of protein using bicinchoninic acid. Anal. Biochem. 150 (1), 76-85.

Steger, K.K., Gardner, J.P., 2007. A laboratory experiments on the effects of variable suspended sediment concentrations on the ecophysiology of the porcelain crab Petrolisthes elongatus (Milne Edwards, 1837). J. Exp. Mar. Biol. Ecol. 344, 181-192.

Sturmbauer, C., Opadiya, G.B., Niederstätter, H., Riedmann, A., Dallinger, R., 1999. Mitochondrial DNA reveals cryptic oligochaete species differing in cadmium resistance. Mol. Biol. Evol. 16 (7), 967-974.

Sundstein, C.M., Nohr, G.R., Kjerulf, P.J., 2010. Degradation of mussel (Mytilus edulis) fecal pellets released from hanging long-lines upon sinking and after settling at the sediment. Can. J. Fish. Aquat. Sci. 67, 1376-1387.

Tacon, A.G.J., Metian, M., 2008. Global overview on the use of fish meal and fish oil in industrially compounded aquafeeds: trends and future prospects. Aquaculture 285 (1) 146-158.

Tamura, K., Nei, N., 1993. Estimation of the number of nucleotide substitution in the control region of mitochondrial DNA in humans and chimpanzees. Mol. Biol. Evol. 10 512-526.

Tamura, K., Peterson, D., Peterson, N., Stecher, G., Nei, M., Kumar, S., 2011. MEGA5: molec ular evolutionary genetics analysis using maximum likelihood, evolutionary distance and maximum parsimony methods. Mol. Biol. Evol. 28, 2731-2739.

Tappel, M.E., Chaudiere, J., Tappel, A.L.L., 1982. Glutathione peroxidase activities of animal tissues. Comp. Biochem. Physiol. B Comp. Biochem. 73 (4), 945-949.

Unrine, J.M., Hopkins, W.A., Romanek, C.S., Jackson, Brian P., 2007. Bioaccumulation of trace elements in omnivorous amphibian larvae: implications for amphibian health and contaminant transport. Environ. Pollut. 149 (2), 182-192.

Valavanidis, A., Vlahogianni, T., Dassenakis, M., Scoullos, M., 2006. Molecular biomarkers of oxidative stress in aquatic organisms in relation to toxic environmental pollutants. Ecotoxicol. Environ. Saf. 64 (2), 178-189.

Walker, T.R., MacAskill, D., 2014. Monitoring water quality in Sydney Harbour using blue mussels during remediation of the Sydney Tar Ponds, Nova Scotia, Canada. Environ. Monit. Assess. 186 (3), 1623-1638.

Walker, T.R.A., Grant, J.B., 2015. Metal(loid)s in sediment, lobster and mussel tissues near historical gold mine sites. Mar. Pollut. Bull. 101 (1), 404-408. 